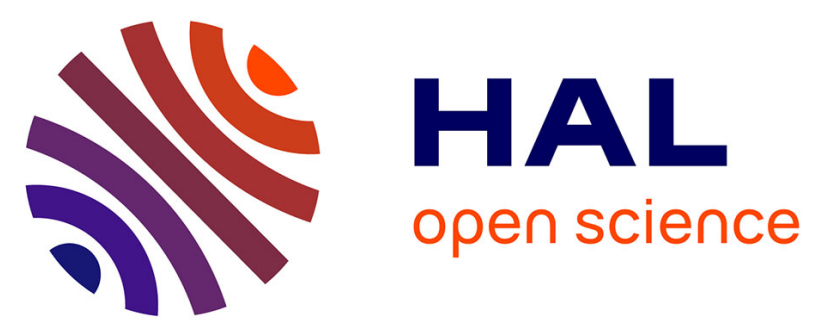

\title{
Long-term fluvial incision rates and postglacial river relaxation time in the French Western Alps from 10Be dating of alluvial terraces with assessment of inheritance, soil development and wind ablation effects.
} G. Y. Brocard, Pieter van Der Beek, D. Bourles, Lionel Siame, Jean-Louis Mugnier

\section{To cite this version:}

G. Y. Brocard, Pieter van Der Beek, D. Bourles, Lionel Siame, Jean-Louis Mugnier. Long-term fluvial incision rates and postglacial river relaxation time in the French Western Alps from 10Be dating of alluvial terraces with assessment of inheritance, soil development and wind ablation effects.. Earth and Planetary Science Letters, 2003, 209, pp.197-214. hal-00096443

\section{HAL Id: hal-00096443 \\ https://hal.science/hal-00096443}

Submitted on 19 Sep 2006

HAL is a multi-disciplinary open access archive for the deposit and dissemination of scientific research documents, whether they are published or not. The documents may come from teaching and research institutions in France or abroad, or from public or private research centers.
L'archive ouverte pluridisciplinaire HAL, est destinée au dépôt et à la diffusion de documents scientifiques de niveau recherche, publiés ou non, émanant des établissements d'enseignement et de recherche français ou étrangers, des laboratoires publics ou privés. 


\section{Long-term fluvial incision rates and postglacial river relaxation}

time in the French Western Alps from ${ }^{10} \mathrm{Be}$ dating of alluvial terraces with assessment of inheritance, soil development and wind ablation effects.

G. Y. Brocard ${ }^{1 *}$, P. A. van der Beek ${ }^{1}$, D. L. Bourlès ${ }^{2}$, L. L. Siame ${ }^{3}$, J-L. Mugnier ${ }^{1}$

${ }^{1}$ Laboratoire de Géodynamique des Chaînes Alpines, Université Joseph Fourier, 38041 Grenoble, France (UMR CNRS 5025)

${ }^{2}$ Centre Européen de Recherche et d'Enseignement des Géosciences de l'Environnement, Université Aix-Marseille 3, 13545 Aix-en-Provence, France (UMR CNRS 6635) ${ }^{3}$ Orsayterre, Université Paris Sud, 91405 Orsay, France (UMR CNRS 8616)

* Present address: Département de Géologie - Morphodynamique continentale et côtière, Université de Rouen, 76821 Mont Saint Aignan (UMR CNRS 6143)

Published in: Earth and Planetary Science Letters, vol. 209, pp. 197-214 


\section{Abstract}

Studying river long-profile development as a response to tectonic and climatic controls requires reliable age-dating of paleo-profile remnants preserved as river terraces. Cosmic Ray Exposure (CRE) dating often represents the only method available to date river terraces, but the interpretation of cosmogenic nuclide concentrations is complicated by pre-depositional inheritance and post-depositional disturbance of the terrace deposits through pedogenesis and surface inflation or deflation. Here, we use cosmogenic ${ }^{10} \mathrm{Be}$ measurements to date alluvial terraces in the French western Alps, in order to estimate river incision rates and to infer river response to climatic fluctuations and tectonic forcing. We assess inheritance by constructing ${ }^{10} \mathrm{Be}$ concentration vs. pebble depth profiles and use a Monte-Carlo technique to estimate terrace ages. We find that inheritance is negligible on all terraces, enabling us to date terraces as young as 5 ky. Terraces that predate the last glaciation experienced intense pedogenesis and wind ablation which led to significant scatter in the ${ }^{10} \mathrm{Be}$ concentrations of surface samples. We assess these effects using a model of ${ }^{10} \mathrm{Be}$ ingrowth and show that the oldest CRE ages of surface clasts are close to the probable terrace age.

We study two catchments which have undergone varying degrees of glacial disruption. The Buëch River experienced variations in runoff and sediment flux during the last glaciation, as well as occasional ice-dammings of its outlet. Its upper terraces record incision rates averaged over $190 \mathrm{ky}$ of $\sim 0.8 \mathrm{~mm} / \mathrm{yr}$, consistent with denudation rates estimated in the surrounding areas and suggesting long-term stability of river incision rates.

Climatic forcing is well documented for the Drac River, which was repeatedly dammed by glaciers during cold periods. Its postglacial incision history was triggered by an 800-m drop in base level following ice-dam disappearance. Long-profile development by knickpoint propagation explains the time-lag of 2-5 ky between this base-level drop and terrace abandonment upstream, as well as subsequent peak incision rates of $>6 \mathrm{~cm} / \mathrm{yr}$ followed by a gradual decrease in incision rates. The present knickpoint location, $\sim 55 \mathrm{~km}$ upstream from the glacial damming site, enables us to calculate a fluvial response time of 15-20 ky, controlled by knickpoint propagation rates of several meters per year, within the Drac River.

Keywords: Cosmic Ray Exposure dating, river terraces, Alps, river long-profile development

\section{Introduction}

Rivers maintain both the transport of debris generated on mountain slopes and the incision of the bedrock, thus creating relief. Both mechanisms regulate erosion on catchment slopes. As the capacity of a river to incise bedrock and transport sediments depends on channel gradient, a positive feedback exists between bedrock uplift and river incision [1]. Relief is therefore thought to evolve toward a dynamic equilibrium between uplift and erosion [1, 2]; such equilibrium is often assumed and used in neotectonic studies to infer uplift rates from river incision rate measurements [e.g., 3, 4, 5]. However, except in the specific conditions of sustained rock uplift and incision rates and climatic stability, rivers will generally not be in dynamic equilibrium and their forms will change over time [2]. Among other parameters, climate fluctuations modify river dynamics and long profile evolution. Thus, the long-term incision signature may be obscured by climatically-induced departures from equilibrium [6, 7]. Studying the development of fluvial 
form over time after some initial disturbance, as well as the timescale of this response, may lead to significant progress in our understanding of the dynamics of, and controls on, bedrock river behaviour [8].

Our study of western alpine rivers analyses the dynamics of bedrock incision on timescales which are ideally suited (1) to assess the long-term, tectonically or isostatically controlled components of incision $\left(10^{5} \mathrm{yr}\right.$ ), and (2) to study the sensitivity of river incision and long profile development to high-frequency climatic events $\left(10^{3}-10^{4} \mathrm{yr}\right)$ in a mountain range which is periodically and extensively glaciated. Climatic forcing may, in fact, strongly control erosion and rock-uplift rates that are measured in the Alps over short timescales $\left(10^{1}-10^{4} \mathrm{yr}\right)$.

The Alps are a moderately active mountain range that experienced widespread glaciation during the Quaternary. We have investigated the incision record in the adjoining watersheds of the Buëch and Drac rivers in SE France (Fig. 1), which exhibit varying degrees of disruption that depend on their distance from the centre of the Alpine glacial ice field (Fig. 2).

The Buëch River experienced successive valley floor widening and narrowing during glacialinterglacial cycles, probably due to runoff and sediment flux variations [e.g., 7]. Parts of the valley floor were abandoned during narrowing events and subsequent river entrenchment, and have been preserved on valley flanks as strath terraces. Their ages and elevations above the active channel record river incision rates. The older terraces permit to determine the long-term component of incision whereas the youngest one documents a climatically-induced fluctuation of the incision rate.

The analysis of the Drac River terraces documents more precisely the river response to a sudden and dramatic disruption: the rapid retreat at the end of the last glaciation of a glacier that dammed the river's lower valley. The fill terraces built upstream from the ice-dam document the response time of the river to this base-level fall, while terraces carved during subsequent river entrenchment record the river long-profile evolution as it evolves toward a profile shape similar to previous interglacial profiles. The terrace ages also help to assess the duration of this relaxation phase.

To constrain incision rates, accurate absolute dating of the terraces is required. The ages of alpine river terraces have traditionally been correlated to the different glacial stages recognized in Western Europe [e.g., 9]. Their mode of deposition results in a lack of suitable organic remains, which has prevented absolute age determinations based on ${ }^{14} \mathrm{C}$ dating. Moreover, this dating method does not extend to the expected age range of some of the terraces. Correlations with specific glacial stages are thus highly speculative and led us to conduct cosmic ray exposure (CRE) dating.

In situ-produced cosmogenic nuclides are now widely used for dating geomorphic surfaces [10, 11]. However, the accumulation history of cosmogenic nuclides in terrace surface samples may be highly complex. Clast inheritance prior to deposition, soil packing, stirring, aeolian deflation and inflation are some of the processes that have to be taken into account when estimating terrace abandonment ages. Techniques that have been proposed to assess the inheritance component include sampling profiles of ${ }^{10} \mathrm{Be}$ concentration with depth and amalgamating samples [12-14]. Here, we employ a single-clast profiling technique and estimate terrace ages and inheritance using a newly developed Monte Carlo approach. The degree of 
pedogenesis is evaluated by geochemical weathering balance measurements and its effects on age scatter tested by numerical modelling.

\section{Geological and glacial setting}

Our study area is located within the Subalpine Chains, the foreland fold-and-thrust belt of the French western Alps (Fig. 1). The Subalpine Chains formed during the Late Miocene by propagation of the orogenic front onto the European foreland [15]. They are composed of a folded Mesozoic sequence of marly and calcareous sediments, deposited on the former European passive margin, as well as remnants of Cenozoic detrital sediments of the Alpine foreland incorporated into the thrust slices.

Tectonic activity within the western Alps decreased after the structuring of the Subalpine Chains, but active tectonics is still documented in some areas. This includes active thrusting along the Subalpine Front, folding in the Subalpine Chains, strike-slip faulting in the External Crystalline Massifs (ECMs) [16, 17], and extensional inversion of inner Alpine thrusts [e.g., 18]. Recent vertical motions are documented in the sediments of the foreland $[19,20]$ and thrusting of the Digne Nappe and adjacent foreland folding continued into the Quaternary [21, 22]. Accelerated Late Cenozoic denudation with rates up to $\sim 1 \mathrm{~mm} \mathrm{y}^{-1}$ is recorded by fission track data from the ECMs [23, 24] and is corroborated by a significant Late Cainozoic increase in sediment accumulation in peri-alpine basins [25]. Present-day differential vertical motions between the Subalpine Chains and the ECMs with respect to the foreland are also of the order of $1 \mathrm{~mm} \mathrm{y}^{-1}[16,17]$, contrasting with negligible present-day convergence rates of $<2 \mathrm{~mm}^{-1}$ [26]. The present-day tectonic activity is poorly understood in the study area, as it lacks a sedimentological record of the deformation as well as striking neotectonic features. Microseismicity measured over the last few decades is low and few historic earthquakes have been recorded.

The Drac and Buëch watersheds extend over a bulk area of $3568 \mathrm{~km}^{2}$ and have comparable lengths and drainage areas (Drac: $125 \mathrm{~km}$ and $2095 \mathrm{~km}^{2}$; Buëch: $70 \mathrm{~km}$ and $1473 \mathrm{~km}^{2}$, respectively). The Drac River drains the resistant crystalline rocks (granite, gneisses and amphibolites) of the Pelvoux ECM in its headwaters before flowing northward into a valley subsequent to an isoclinal structure of the Subalpine sedimentary cover. The Buëch River flows exclusively within the Subalpine formations, through complex interference structures between Eocene and Miocene folds. Within the study area, the Subalpine sedimentary cover is composed of very thick (up to $2000 \mathrm{~m}$ ) marly formations, interbedded with thin (20 to $80 \mathrm{~m}$ ) levels of highly resistant massive limestones, in addition to thicker (up to $300 \mathrm{~m}$ ) but softer rhythmic successions of marls and marly limestones.

Both rivers lie off the western margin of the glacial alpine ice field (Fig. 2). Because of its low elevation (mean elevation: $1067 \mathrm{~m}, 4 \%$ of relief over $1600 \mathrm{~m}$ ), the Buëch watershed remained under the glaciation threshold during all glacial periods. The mean elevation of the Drac watershed is higher (1487 m, $39 \%$ of relief over $1600 \mathrm{~m}$ ) and some valley glaciers have been generated in its headwaters. Ice occupation of the main trunk valleys, however, occurred mainly by overflows (diffluences) of outlet glaciers of the inner alpine ice-field. The Durance glacier spilled into both the Drac and Buëch watersheds through the Bayard 
and Freyssinouse passes (Fig. 2). During the most intense glaciations (e.g., $\delta^{18} \mathrm{O}$ isotopic stage 6), the Durance glacier dammed the Buëch River outlet and flowed upstream into the lower Buëch valley (Fig. 3). The Isère glacier caused similar damming at the Drac-Isère confluence during less intense glacial advances (Fig. 2). During stronger glacial invasion, the Drac River experienced additional damming by mountain glaciers flowing down the Pelvoux ECM [27, 28].

\section{Formation of terraces}

\subsection{Buëch River terraces}

The Buëch River preserves both strath and fill terraces (as defined by Bull [29]). The older terraces along its lower reaches have been strongly eroded by the Durance ice stream. Similarly, the Freyssinouse diffluent ice tongue has eroded some terraces of the Petit Buëch River located along its course. The ice-free portion of the Buëch catchment contains three well-preserved terraces (T1b, T2, T3) whose surfaces stand 20, 80 and $190 \mathrm{~m}$ above the present-day valley floor, respectively (Fig. 3). At the catchment scale, terrace formation only occurs along the diffluent glacier outwash path, that is, along the present Petit Buëch and Lower Buëch rivers, and appears to be strongly controlled by the diffluent glacier meltwater discharge. The two upper levels (T3 and T2) are fill terraces characterized by wide and flat straths capped with 50-55 m and 15-20 m of alluvial deposits, respectively, and thus record phases of aggradation alternating with downcutting. The alluvial deposits contain a large proportion of quartzitic and crystalline pebbles. These rocks do not crop out in the Buëch watershed: they have been brought in from the Durance catchment by the Freyssinouse ice-tongue. Fluvial aggradation is a common phenomenon in front of the alpine glaciers and was probably triggered by the inability of rivers to carry the glacial bedload. In this particular case, aggradation appears to be triggered mainly by episodic ice damming of the lower river reaches when the Durance glacier reached its greatest extents (Fig. 3).

The lowest level (T1b) terraces are strath terraces. Their deposits are much thinner than those of the upper two levels. This lowest level may record a major modification of the Buëch river dynamics driven by climate change after the complete disappearance of the Freyssinouse ice tongue [30].

\subsection{Drac River terraces}

Most of the Drac River terraces older than the Last Glacial Maximum (LGM) have been covered by ice and strongly eroded [28]. We focus therefore on the post-LGM history of the Drac River. Two kinds of postglacial terraces can be distinguished (Figs. 4 and 5): high-standing fill terraces that are linked to glacial disturbance of the river profile and lower strath terraces cut during postglacial river incision.

Fill terraces comprise depositional sequences up to $450 \mathrm{~m}$ thick that infill a valley network which predates the LGM $[27,28]$. Repeated glaciations induced several cycles of valley filling and subsequent downcutting with superimposition, and led to the present complex of cross-cutting buried drainages. The buried valleys exhibit steep V-shaped cross-sections with very narrow bedrock floors (a few tens to a few hundreds of metres wide), giving rise to a very irregular bedrock surface (cf. Fig. 5). The depositional facies 
of the fill sequences generally grade upward from fluvial to transgressive lacustrine and back to fluvial. Sediments were trapped upstream of a suite of glacial dams blocking the Drac valley and its tributaries during the LGM. Throughout glacial retreat, glacially-dammed and trough lakes were formed in the vicinity of the shrinking ice masses and were rapidly filled with sediments. Fill terraces are therefore diachronous, the most recent troughs being filled as river entrenchment had begun in the former ice-dam deposits.

Numerous unpaired strath terraces were abandoned throughout river entrenchment and are cut either into bedrock or into buried ancestral valley fill deposits [28]. The strath terraces of the postglacial valley were preferentially carved and/or preserved in soft bedrock types (marls). The amount of incised bedrock is highly variable along the river, depending on the distance between the present-day river valley and buried paleovalley axes (Fig. 5). The eroded bedrock is made up of thick, strongly folded Mezosoic marly limestones and marls, thinner series of resistant limestones, and, along some reaches, Paleozoic gneisses and Triassic evaporites and basalts. Maximum overall postglacial incision amounts to $450 \mathrm{~m}$; maximum entrenchment into bedrock is $370 \mathrm{~m}$.

\section{Sampling strategy and concentration-to-age conversion.}

\subsection{Laboratory methods and single-clast age calculations}

We extracted quartz from granite, gneiss, sandstone or quarzite pebbles. Quartz grains isolation and dissolution, ${ }^{9} \mathrm{Be}$ spike addition and alkaline precipitations of $\mathrm{Be}$ were performed following [31]. Measurements of ${ }^{10} \mathrm{Be}$ concentration were performed on the Tandetron Accelerator Mass Spectrometry (AMS) facility at Gif-sur-Yvette, France. The ${ }^{10}$ Be analyses were calibrated against NIST Standard Reference Material 4325. Results are given in table 1.

Altitudinal and latitudinal variations in cosmogenic nuclide production rate are commonly modelled using empirical polynomials [32-34]. At the latitudes and altitudes of our study region, these different models do not yield significantly different production rate corrections (less than $4 \%$ ). We use the calibrated high-latitude sea level production rate of 5.75 \pm 0.24 atom g ${ }^{-1} \mathrm{y}^{-1}$ [35] derived from an Austrian landslide located in the same latitudinal and altitudinal range as our study area, corrected for latitude and elevation using the correction factors of Dunai [33]. Topographic shielding was calculated using Heidbreder formulations [36]. Production rates were corrected for depth dissipation in alluvial sediments using:

$$
C(x, t)=C(0) \cdot e^{-\lambda t}+\left(1-e^{-\lambda t}\right) \frac{P_{0}}{\lambda}\left(\left(P_{0}\left(1-F_{\mu}\right) e^{\frac{-\rho x}{\Lambda_{n}}}\right)+\left(P_{0} F_{\mu} e^{\frac{-\rho x}{\Lambda_{\mu}}}\right)\right)
$$

where $C(x, t)$ is the concentration of ${ }^{10} \mathrm{Be}$ as a function of time $(t)$ and depth $(x), P_{0}$ is the local production rate (atom $\left.\mathrm{g}^{-1} \mathrm{y}^{-1}\right), \lambda$ is the radioactive decay constant $\left(\mathrm{yr}^{-1}\right), C(0)$ is the inherited cosmogenic nuclide concentration at the initiation of the surface exposure episode, $\rho$ is rock density $\left(\mathrm{g} \mathrm{cm}^{-3}\right), F_{\mathrm{n}}$ and $F_{\mu}$ are the 
neutron and muon contribution to the total production rate, respectively (where $F_{\mu}=0,015 F_{\mathrm{n}}$ at the surface, [37]) and $\Lambda_{\mathrm{n}}\left(\sim 150 \mathrm{~g} \mathrm{~cm}^{2}\right)$ and $\Lambda_{\mu}\left(\sim 1300 \mathrm{~g} \mathrm{~cm}^{2}\right)$ are the attenuation lengths of neutrons and muons, respectively [38].

\subsection{Treatment of inheritance: Profiling technique}

In order to overcome problems of inheritance and disparate exposure histories, we employed wherever possible a profiling technique in which 3 to 5 samples up to a depth of 2-3 meters were analysed (Table 1). After a detailed inspection of terraces along both rivers, we selected sample sites on terraces with flat, horizontal surfaces, where the soil structure did not show any sign of terrace disturbance or deflation. Along the Drac River, sampling sites were either quarries or actively eroding terrace edges, where the undisturbed nature of the fluvial bedding could be ascertained and where the exposure time of vertical side walls is negligible compared to that of the surface. Each clast accumulates some ${ }^{10} \mathrm{Be}$ during exhumation and subsequent transport in the catchment prior to its final deposition at the terrace surface. The amount of inherited ${ }^{10} \mathrm{Be}$ is specific for each clast and can be assessed statistically in some catchments [12]. Whereas this inheritance varies randomly with depth, in situ post depositional cosmogenic accumulation decreases exponentially.

We use a Monte Carlo technique to estimate terrace ages by generating large sets of theoretical depth-concentration curves from equation (1), randomly varying inheritance $(C(0))$, age $(t)$ and soil density ( $\rho$ ). Soil density is allowed to vary between 1.7 and $2.3 \mathrm{~g} \mathrm{~cm}^{-3}$ as the porosity of the fluvial deposits is highly variable in the studied terraces. Models are accepted if they fit all the data points within error. Best-fitting models are then defined based on least-squares residuals and define the estimated 'optimal' terrace ages. As there is a trade-off between the various input variable, more than one best-fit solution can be found. The ages of the best-fitting models span an interval indicated in the plots of Fig. 6.

An upper limit to the amount of inherited ${ }^{10} \mathrm{Be}$ is fixed by the maximum ${ }^{10} \mathrm{Be}$ concentration within the deepest sample (the "mineralogical blank"). Inherited ${ }^{10} \mathrm{Be}$ is produced chiefly during the final denudation of clasts on catchment slopes. The fluvial transport time is generally low in comparison with the denudation time, and systematic downstream increases of inheritance are rarely observed [39]. The set of mineralogical blanks can thus be used to evaluate the variability of inheritance throughout the catchment. All the mineralogical blank concentrations are very low and comparable to the process blanks treated in the same way as the samples. Low inheritance is also evidenced by the good fit of the observed concentrations with a purely exponential depth-concentration model (Fig. 6). Inherited ${ }^{10} \mathrm{Be}$ in our samples is equivalent to an in situ accumulation of 1.0 to $2.3 \mathrm{ky}$ for a surface undergoing no erosion.

Because of the low inheritance, we are able to reliably date terraces as young as 4-5 ky (e.g., Drac 6, Fig. 7). The low inheritance does not, however, imply exceedingly high erosion rates within the Drac and Buëch catchments. Most of the denudation of the crystalline basement probably occurs under ice cover during glacial times, as the Pelvoux Massif stands at high elevations, and by catastrophic rock falls following glacier retreat. This is evidenced in the Pelvoux ECM by very intense rock-fall activity that led to a continuous filling and reshaping of the glacial valleys since the LGM. Most of the clasts have thus probably 
either been shielded from cosmic rays in scree deposits, or carried within the ice and stored in the thick sedimentary bodies of the buried valleys described previously. The fill terraces studied here were located at most a few kilometres downstream of the glacier fronts and a few tens of kilometres from clast source areas. The younger strath terraces, carved during the subsequent river intrenchment, probably contain a significant proportion of clasts removed from river deposits infilling the ancient drainages. The overwhelming majority of the clasts within those deposits were buried at depths that prevented ${ }^{10} \mathrm{Be}$ accumulation.

Field observations of terrace structures provide evidence for the pristine nature of the surfaces. Their general flatness precludes transport of clasts over long distances by any natural processes under the postglacial climate. No erosion factor is thus applied to the models (Eq. 1). Some terraces, however, have been ploughed at a millennial timescale to depths that nowhere exceed $40 \mathrm{~cm}$. Cereal cultivation first appears in pollen records within the Drac and Buëch River watersheds around 5 ky BP [40, 41]. Repeated ploughing could have induced lateral diffusion of surface clasts and soil deflation, thus producing minimum cosmogenic ages. As the terrace surfaces are wide and flat, lateral loss of material is believed to be negligible, and anthropogenic disturbances should thus have little effect on concentrations underneath the ploughed layer.

\subsection{Assessment of deflation on old terraces}

Given that the T2 and T3 terrace levels along the Buëch River were expected to be much older than the Drac River terraces, and that inheritance is very low in T1 terrace clasts, this factor is likely negligible in T2 and T3. In contrast, we expect post-depositional terrace disturbance to be an important issue on these terraces. The profiling technique was therefore replaced by surface sampling of large quartzite cobbles on T2 and T3 (Table 1). T2 and T3 terrace treads are nearly perfectly flat and are currently disconnected from the valley sides; terrace surfaces are flat tens to hundreds of meters away from the sampling sites. The T2 terrace remnants were cultivated in historical times. The T3 level terraces are forested, their soils being too poor for agricultural use.

Apparent exposure ages are between 10 and 60 ka for T2 (Buëch 2) and between 143 and 189 ka for T3 (Buëch 1). However, field data allow us to better constrain the ages of terrace abandonment. The T3 terrace level was constructed by alluvium delivered to the Buëch catchment by the Freyssinouse diffluent ice-tongue and by ice-damming of the lower valley by the Durance glacier. Thus, T3 must have been formed during one of the glacial peaks preceding the apparent age of the most exposed clast (188 ky). The closest peak is $\delta^{18} \mathrm{O}$ stage 6.6, at $190 \mathrm{ky}$, which corresponds to the onset of the "Riss 2" alpine glaciation. The next older peak is located at the end of an earlier glaciation, at $245 \mathrm{ky}\left(\delta^{18} \mathrm{O}\right.$ stage 8.1$)$. As the ages obtained by random sampling of the terrace surface range between 140 and $190 \mathrm{ky}$, deposition of the alluvium likely occurred during $\delta^{18} \mathrm{O}$ stage 6.6. Likewise, the apparent age of sample Buëch 2-1 sets a minimum possible age for T2 terrace abandonment. As for T3, this age is slightly younger than the first cold peak of a glaciation ( $\delta^{18} \mathrm{O}$ stage 4; $75 \mathrm{ky}$ ). T2 likely formed in the same way as T3, at the inception of a glacial cycle.

We suggest that soil development may be responsible for much of the observed scattering of apparent ages on both terraces. In Western Europe, north of the Mediterranean climatic zone, soils evolve 
toward chromic alisols [42]. Weathering is characterized by a dramatic loss of matter, and several meters of surface lowering have been estimated on terraces of similar composition and ages in the nearby Rhône valley [43]. Field observations of terrace soils suggest that rapid deflation in the first stages of soil development (rhodic cambisol) is triggered by the complete dissolution of carbonates. Depletion in the upper soil horizons is then achieved by weathering and disintegration of crystalline clasts, in addition to illuviation of the silty matrix. The present-day surfaces are composed of quartzite pebbles supported by a silty matrix of clay minerals and detrital quartz grains. The density of quartzite pebbles on the surface is significantly higher than in the soil. Thus, the quartzite pebbles that are currently exposed at the surface were initially located at shallow but varying depths and were brought to the surface by erosion of the silty matrix. From their exhumation onward, they underwent a similar cosmogenic nuclide accumulation history.

To assess the younging effect of deflation, we conducted geochemical weathering balance measurements on the T3 terrace (Buëch 1 sampling site). Soil was sampled in the upper $50 \mathrm{~cm}$ below the surface and compared to fresh alluvium sampled at a depth of $30 \mathrm{~m}$. Trace element abundances were determined by inductively coupled plasma mass spectroscopy (ICP-MS) at the Laboratoire de Géodynamique des Chaînes Alpines, Grenoble, France. Major element geochemistry was determined by ICP-AES spectrometry at the Centre de Recherches Pétrographiques et Géochimiques, Nancy, France. Immobility of the most refractory elements was tested using the element concentration ratio method [e.g. 44]. Nb, Ta and Th ratios vary the least between soil and alluvium; they are thus considered to have the lowest mobility's. These elements were used to assess the minimum loss of the other elements (Table 2). Lambert calcimetry measurements further indicate that the carbonates, which disappeared in the early stages of weathering, amount to $50-60 \%$ of the mass of the fresh alluvium. Weathering balance calculations indicate that the quartzite environment experienced an additional loss that does not exceed $10 \%$. At this stage of pedogenesis, the dissolution of carbonates thus accounts almost completely for the observed loss of matter. The accuracy of the measurements is limited by the structure and porosity of the fresh deposits. The terrace deposits are channelized; the size distribution of clasts is heterogeneous from one channel to another and the distribution of rock types depends on clast size. It is thus not possible to establish whether the channel sampled at depth has the same initial composition as the channel that produced the soil. The porosity of the fresh alluvium further enhances deep illuviation of clays, so that the observed element mobility not only depends on chemical properties. Finally, the soil density may be different from that of the fresh alluvium.

The effect of pedogenesis on apparent age scattering was evaluated by numerical modelling of ${ }^{10} \mathrm{Be}$ ingrowth, using the following constraints (Fig. 8): (1) Deposition of the alluvium likely occurred during $\delta^{18} \mathrm{O}$ stage 6.6, at $190 \mathrm{ka}$; (2) We assume that soil development was negligible during the entire "Riss 2" glaciation. The terrace surface was armoured with pebbles at this time so that no wind erosion could occur; (3) Close to the surface, most of the pedogenesis probably occurred during Eemian interglacial times ( 13075 ky B.P.), when the region was densely forested [45]. However, the attenuation of cosmic rays by the vegetation cover is considered negligible, as it is nowadays even in densely forested tropical areas [46]; (4) The disappearance of the vegetation cover during the last glaciation led to the final exhumation of the 
quartzite pebbles now scattered at the surface. Pebbles were embedded in a silty soil matrix which was readily carried away by wind. Wind ablation stopped at ca $\sim 15 \mathrm{ky}$ B.P. when pine forests began to develop [30, 40]; (5) Postglacial pedogenesis did not modify the matrix, which had already been strongly weathered during the Eemian interglacial stage.

Two denudation paths have been tested: the first with an exponentially decreasing dissolution of carbonates, and the second with a constant dissolution rate. The rate of dissolution was calibrated using the current carbonate dissolution at the Drac 1 sampling site (6\% within $12 \mathrm{ky}$ ). Using this number, we calculate an initial carbonate dissolution rate, corrected for the initial carbonate content of the T3 terrace, of $0.9 \%$ per ky.

The modelling results show that pedogenesis on its own can account for most of the observed age scatter of the T3 terrace, and that the oldest ages obtained from CRE dating are close estimates of the actual terrace age. If we assume that aeolian ablation is responsible for the exhumation of the quartzite pebbles and that ablation occurred during the last glaciation, a constant rate of erosion between 20 and $40 \mathrm{~mm} \mathrm{ky}^{-1}$ is necessary to bring pebbles to the surface with apparent ages as young as Buëch 1-3, dated at 140 ky.

The larger age scatter of the Buëch 2 samples (10-60 ky) cannot be explained solely by soil development. The terrace from which they were sampled (T2) is much younger than T3, and its alluvial sediment composition is similar. At the sampling site, the surface exhibits an immature dry soil and strong dissolution features on carbonate pebbles that indicate the development of relatively evolved soils during interstadial and postglacial times. The T2 terrace probably experienced more agricultural turbation and deforestation than T3, because its soil was more fertile. The soil could have been exposed annually to ploughing and wind deflation over the last $5 \mathrm{ky}$.

\section{Discussion: climatic and tectonic controls on river incision}

\subsection{Buëch River: long-term incision rates and climatic variability}

In order to assess incision rates from the ages and elevations of the T2 and T3 terraces, we consider two end-member models (Table 3). A minimum rate (1) is obtained considering that (a) the terrace age is set by the end of the glacial peak preceding the age of oldest dated pebble and (b) the rate of incision into the alluvial terrace deposits is much higher than the rate of incision into the underlying bedrock. A maximum rate (2) is obtained considering that (a) terraces are not older than the oldest dated pebbles and (b) the incision rate is constant through the terrace deposits and the underlying bedrock. The results are consistent with an approximately constant long-term incision rate of the Buëch River since 190 ky (Fig. 9). As aggradation on the T2 and T3 strath terraces stems from ice-damming of its lowest valley, incision probably occurs very rapidly in these readily erodible sediments, as observed in the Drac catchment (see below). The long-term incision rate of the Buëch River is therefore probably slightly greater than our lower estimate, i.e. $\sim 0.8 \mathrm{~mm} \mathrm{yr}^{-1}$.

The highest terraces provide a good estimate of the long-term local incision rate integrated over several climatic cycles [e.g., 6]; their parallelism with the modern river indicates that this rate was constant 
along the studied reach. The incision rate is consistent with the denudation rates of $1.0 \pm 0.5 \mathrm{~mm} \mathrm{yr}^{-1}$ in the ECM over the last few My as inferred from fission-track cooling ages [23, 24], suggesting that these rates may be constant at a timescale of $10^{5}-10^{6} \mathrm{yr}$. These rates are surprisingly high given the relative tectonic quiescence of the western Alps since late Miocene times. However, they are corroborated by sediment flux data that also show a significant increase during the Quaternary [25]. Local incision as well as regional denudation may be driven by tectonic or isostatic uplift of the mountain range. Coeval downwarping of the foreland [19, 20] would argue for an isostatic uplift mechanism, driven by relatively rapid and localised Quaternary erosion and relief production within the western Alps.

The T1b terrace level documents an apparent increase in incision rates from $\sim 1$ to $3 \mathrm{~mm} \mathrm{yr}^{-1}$ in the last several thousand years. Climatic fluctuations may have affected the incision rate either by fluvial dynamic forcing or by glacio-isostasy. Fluvial dynamic fluctuations are responsible for strath terrace formation along an incising river by successive widening and narrowing of the valley floor [e.g., 29]. Various authors have addressed the problem of how the incision rate would evolve coevally. Widening could result either from an increase in excess stream power available for lateral bank erosion under constant incision rates [47], or by pauses in long-term downcutting [48]. In the latter scenario, the formation of T1b may have coincided with strongly reduced incision rates. As incision resumes and T1b is abandoned, the Buëch River would have kept pace with rock uplift by accelerated downcutting, as suggested by the postabandonment incision rate integrated over the last 8 ky estimated from the Buëch 3 samples. Similar Holocene accelerations in apparent incision rates have been observed in other catchments [6, 7] and are generally interpreted to reflect the adaptation of the rivers to decreased postglacial sediment fluxes. We concur with such a scenario, which implies that periods of slow incision or aggradation with recurrence times greater than that elapsed since T1 abandonment should have occurred since the formation of the T2 and T3 terraces.

Postglacial isostatic rebound may also have enhanced uplift and incision to some extent in the case of rapid shrinking of the ice-cap. It is worth noting that valley glaciers up to $2 \mathrm{~km}$ thick extended over the inner Alps and that glacier retreat was dramatic around $14 \mathrm{ky}$ cal B.P. [49], so that the effects of isostatic rebound could be significant. However, its amplitude has not been quantified so far in the Alps.

\subsection{Drac River: response time to glacial disturbance}

The oldest terrace dated along the Drac River is of LGM age (Drac 5). The Drac 5 terrace fills a trough lake surrounded by the external moraines of the Séveraisse Glacier (Fig. 4b). Its age suggests that this tributary glacier had begun to retreat at the latest after 23 ka B.P. Shrinkage of alpine glaciers is known to slightly predate the isotopic LGM and has also been documented for the neighbouring Durance [50] and Rhône [51] glaciers.

The postglacial evolution of the Drac River is mainly controlled by the behaviour of the Isère Glacier. At its maximal extent, this major alpine glacier had invaded the lower reaches of the Drac River catchment over $20 \mathrm{~km}$ and elevated the river base level from $200 \mathrm{~m}$ to $1000 \mathrm{~m}$ (Fig. 10). If we assume that glacier fluctuations are synchronous throughout the Western Alps at the millennial timescale, the Isère 
glacier would have started to retreat at the latest at $23 \mathrm{ky}$ B.P. The glacier should have withdrawn from the Isère-Drac confluence around $14 \mathrm{ky}$ at the latest because it had already liberated the Bourget and Annecy lakes, some $70 \mathrm{~km}$ upstream, by this time [52]. The dramatic retreat of Alpine glaciers recorded at around 14 ky can be correlated with a sudden increase in climate warming at this time in Europe [49].

Postglacial long profile re-equilibration of the Drac River is dominated by vigorous incision triggered by the $800 \mathrm{~m}$ base-level drop at the river outlet. The young abandonment age (8-12 ka) of the Drac 1 terrace indicates that several thousand years elapsed between glacial retreat and the onset of incision in this relatively downstream reach. Underlying glacio-lacustrine sediments were eroded at a mean rate greater than $6 \mathrm{~cm} \mathrm{y}^{-1}$ over less than $5.2 \mathrm{ky}$ between the abandonment of the Drac 1 and Drac 7 terraces. Incision rates then dropped to $0.8-1.1 \mathrm{~cm} \mathrm{y}^{-1}$ in alluvial sediments and marly bedrock over the last $7 \mathrm{ky}$. The initial lag, sudden and exceedingly rapid incision and subsequent relaxation are symptomatic of fluvial incision by knickpoint propagation. The knickpoint would originally have been located in the lower valley where the Drac River spilled across reaches that had been over-steepened by glacial erosion (Fig. 10). Knickpoint retreat has been observed in horizontally-layered heterogeneous lithogies [53, 54] and massive rocks [55] but knickpoint preservation during migration is difficult to generate in unconsolidated substrate [56]. In our case, knickpoint lips would have propagated from the ice margins upstream across a suite of paleovalley fills. The river later encountered the buried bedrock palaeodivides, were the current river exhibits small knickpoints correlated with the lithology.

To detect the propagating knickpoint's current location along the Drac River, we have projected the river profile on a DS plot, that is, a plot of the logarithm of slope against the logarithm of downstream distance [57] in Fig.11. Numerous knickpoints break the current river long-profile; all but one correspond to lithological discontinuities. This latter knickpoint splits the DS form of the long-profile into two roughly straight and parallel segments. This knickpoint is an unstable form, located $~ 55 \mathrm{~km}$ upstream of the Isère Glacier tip, within an alluvial reach of the Drac River. Incision rates from dated terrace remnants are lower upstream (Drac 8; 3.9-5.3 mm.yr ${ }^{-1}$ ) than downstream (Drac 6; 6.4-8.4 mm.yr ${ }^{-1}$ ) of this knickpoint, confirming our interpretation of this feature as a degraded retreating knickpoint. If generated at the Isère Glacier tip at 25-18 ky B.P., the knickpoint would have migrated upstream at rates of 2.2-3.0 $\mathrm{m} \mathrm{y}^{-1}$. The gradual temporal decrease of incision rates and the presence of a relict retreating knickpoint far in the headwaters indicate that the Drac River longitudinal profile is about to be graded to the interglacial base level. The river response time to glacial-interglacial long-profile disturbance is therefore of the order of $\sim 20 \mathrm{ky}$.

\section{Conclusions}

Our study illustrates the power of CRE dating of alluvial terraces to study river incision and response to climate fluctuations, and indicates prospective solutions to the complexities involved in estimating alluvial terrace ages from CRE data. We have shown how a combination of depth profiles, numerical modelling and geochemical mass balance studies may be used to assess sample inheritance and terrace deflation in order to correct the inferred abandonment ages. Inherited ${ }^{10} \mathrm{Be}$ concentrations are remarkably low in all studied 
terraces and permit reliable dating of terraces as young as 4-5 ky. Older terraces have undergone significant mass loss through pedogenesis and aeolian ablation; forward models of ${ }^{10} \mathrm{Be}$ ingrowth show, however, that the age of the oldest clast sampled at the surface provides a reliable estimate of the abandonment age.

The Buëch River terraces record a mean long-term fluvial incision rate of $\sim 0.8 \mathrm{~mm} \mathrm{y}^{-1}$ over the last $190 \mathrm{ky}$, similar to long-term denudation of the External Crystalline Massifs [23, 24]. This suggests that river incision is constant at a time scale of $10^{5}-10^{6} \mathrm{y}$. In more detail, however, the data are consistent with significant short-term variations in incision rates driven by climatic fluctuations. The high rates of river incision and regional denudation, in the absence of well-expressed tectonic activity, may be maintained by the isostatic response to rapid Quaternary erosion and relief production in the western Alps. However, given the limited amount of data currently available, dynamic equilibrium sustained by tectonic uplift cannot be definitively excluded in this area.

The 100-km long Drac River experienced base level fluctuations of several hundreds of metres amplitude during glacial advances and retreats. Adjustment to the postglacial base level is achieved by knickpoint retreat over tens of kilometres through successions of unconsolidated sediment and resistant folded bedrock knobs. The time required by the Drac River to achieve re-equilibration of its long-profile at ( $\sim 20 \mathrm{ky}$ ) is comparable to the mean duration of the interglacial times during the Quaternary. It thus seems unlikely that the Drac River, or any other river located inside the glaciated inner Alps has ever reached equilibrium during the Quaternary. Our study therefore shows that care should be taken when using such rivers to infer tectonic uplift from river incision.

\section{Acknowledgments}

Funding for this project was provided by the Institut National des Sciences de l'Univers (INSUCNRS) through Programme National de recherche Sols et Erosion project 99PNSE07. We thank Julien Carcaillet (CEREGE) for indispensable help during cosmogenic target preparation, and Catherine Chauvel and Francine Keller (LGCA) for advice and help in the geochemical analyses. We also thank Paul Bishop, Frank Pazzaglia and an anonymous reviewer for their thorough and constructive reviews of the manuscript. 


\section{References}

$1 \quad$ K.X. Whipple and G.E. Tucker, Dynamics of the stream-power river incision model: Implications for height limits of mountain ranges, landscape response timescales, and research needs, Journal of Geophysical Research 104, 17661-17674, 1999.

2 K.X. Whipple, Fluvial landscape response timescale: How plausible is steady-state denudation?, American Journal of Science 301, 313-325, 2001.

3 J. Leland, M.R. Reid, D.W. Burbank, R. Finkel and M. Caffee, Incision and differential bedrock uplift along the Indus River near Nanga Parbat, Pakistan Himalaya, from ${ }^{10} \mathrm{Be}$ and ${ }^{26} \mathrm{Al}$ exposure age dating of bedrock straths, Earth and Planetary Science Letters 154, 93-107, 1998.

4 D.J. Harbor, Dynamic equilibrium between an active uplift and the Sevier River, Utah, Journal of Geology 106, 181-194, 1998.

5 J. Lavé and J.P. Avouac, Fluvial incision and tectonic uplift across the Himalayas of central Nepal, Journal of Geophysical Research 106, 25561-25593, 2001.

6 F.J. Pazzaglia and M.T. Brandon, A fluvial record of long-term steady-state uplift and erosion across the Cascadia forearc high, western Washington State, American Journal of Science 301, 385-431, 2001.

7 G.S. Hancock and R.S. Anderson, Numerical modeling of fluvial strath-terrace formation in response to oscillating climate, Geological Society of America Bulletin 114, 1131-1142, 2002.

8 J.D. Stock and D.R. Montgomery, Geologic constraints on bedrock river incision using the stream power law, Journal of Geophysical Research 104, 4983-4993, 1999.

9 P. Mandier, Signification dynamique et climatique des formations et terrasses fluviatiles Quaternaires dans les Alpes et leur périphérie, Bulletin de l'Association Française pour l'Etude du Quaternaire 1984(1-3), 113-118, 1984.

10 P.R. Bierman, Using in situ produced cosmogenic isotopes to estimate rates of landscape evolution: A review from the geomorphic perspective, Journal of Geophysical Research 99, 13885-13896, 1994.

11 T.E. Cerling and H. Craig, Geomorphology and in-situ cosmogenic isotopes, Annual Review of Earth and Planetary Sciences 22, 273-317, 1994.

12 R.S. Anderson, J.L. Repka and G.S. Dick, Explicit treatment of inheritance in dating depositional surfaces using in situ ${ }^{10} \mathrm{Be}$ and ${ }^{26} \mathrm{Al}$, Geology 24, 47-51, 1996.

13 J.L. Repka, R.S. Anderson and R. Finkel, Cosmogenic dating of fluvial terraces, Fremont River, Utah, Earth and Planetary Science Letters 152, 59-73, 1997.

14 L.A. Perg, R.S. Anderson and R.C. Finkel, Use of a new ${ }^{10} \mathrm{Be}$ and ${ }^{26} \mathrm{Al}$ inventory method to date marine terraces, Santa Cruz, California, USA, Geology 29, 879-882, 2001.

15 Y. Philippe, E. Deville and A. Mascle, Thin-skinned inversion tectonics at oblique basin margins: example of the western Vercors and Chartreuse Subalpine massifs (SE France), in: Cenozoic 
Foreland Basins of Western Europe, A. Mascle, C. Puigdefàbregas, H.P. Luterbacher and M. Fernàndez, eds., Geological Society Special Publication 134, pp. 239-262, 1998.

F. Jouanne, N. Génaudau, G. Ménard and X. Darmendrail, Estimating present-day displacement fields and tectonic deformation in active mountain belts: an example from the Chartreuse Massif and the southern Jura Mountains, western Alps, Tectonophysics 296, 403-419, 1998.

17 J. Martinod, F. Jouanne, J. Taverna, G. Ménard, J.F. Gamond, X. Darmendrail, J.C. Notter and C. Basile, Present-day deformation of the Dauphiné (SE France) Alpine and Subalpine massifs, Geophysical Journal International 127, 189-200, 1996.

P. Tricart, S. Schwartz, C. Sue, G. Poupeau and J.M. Lardeaux, La dénudation tectonique de la zone ultradauphinoise et l'inversion du front briançonnais au sud-est du Pelvoux (Alpes occidentales): une dynamique miocène à actuelle, Bulletin de la Société géologique de France 172, 49-58, 2001.

A. Bonnet and M. Bornand, Pédologie et Quaternaire dans la vallée du Rhône moyen, Bulletin de l'Association Française pour l'Etude du Quaternaire 1970(2/3), 105-115, 1970.

P. Mandier, Le relief de la moyenne vallée du Rhône au Tertiaire et au Quaternaire. Essai de synthèse paléogéographique, 865 pp., Bureau de Recherches Géologiques et Minières, Orléans, 1988.

J.J. Dufaure, La néotectonique méditerranéenne et ses relations avec la morphogénèse villafranchienne, Bulletin de l'Association Française pour l'Etude du Quaternaire 1983(2/3), 103-121, 1983.

J.-C. Hippolyte and T. Dumont, Identification of Quaternary thrusts, folds and faults in a low seismicity area: examples in the Southern Alps (France), Terra Nova 12, 156-162, 2000.

D. Seward, M. Ford, J. Bürgisser, H. Lickorish, E.A. Williams and L.D. Meckel III, Preliminary results of fission-track analyses in the southern Pelvoux area, SE France, in: 3rd Workshop on Alpine Geological Studies, G. Gosso, F. Jadoul, M. Sella and M.I. Spalla, eds., Memorie di Scienze Geologiche 51, pp. 25-31, 1999.

24 F. Bigot-Cormier, G. Poupeau and M. Sosson, Dénudations différentielles du massif cristallin externe alpin de l'Argentera (Sud-Est de la France) révélées par thermochronologie traces de fission (apatites, zircons), Comptes Rendus de l'Académie de Sciences de Paris 330, 363-370, 2000.

J. Kuhlemann, W. Frisch, B. Székely, I. Dunkl and M. Kázmér, Post-collisional sediment budget history of the Alps: tectonic versus climatic control, International Journal of Earth Sciences 91, 746774818-837, 2002.

26 E. Calais, J.-M. Nocquet, F. Jouanne and M. Tardy, Current strain regime in the Western Alps from continuous Global Positioning System measurements, 1996-2001, Geology 30, 651-654, 2002.

27 G. Montjuvent, La transfluence Durance-Isère. Essai de synthèse du Quaternaire du bassin du Drac (Alpes françaises), Géologie Alpine 49, 57-118, 1973.

G. Montjuvent, Le Drac. Morphologie, stratigraphie et chronologie quaternaires d'un bassin alpin, 433 pp., Comité National de la Recherche Scientifique, Paris, 1978. 
W.B. Bull, Geomorphic Response to Climate Change, 326 pp., Oxford University Press, New York, 1991.

30 T. Rosique, Morphogénèse et évolution des paléoenvironnements alpins de la fin des temps glaciaires au début de l'holocène, Ph.D., Université d'Aix-Marseille I, 1996.

31 D.L. Bourlès, Etude de la géochimie de l'isotope cosmogénique ${ }^{10} \mathrm{Be}$ et son isotope stable ${ }^{9} \mathrm{Be}$ en milieu océanique. Application à la datation de sédiments marins, Ph.D., Université Paris-Sud, 1988.

32 D. Lal, Cosmic ray labelling of erosion surfaces: in situ nuclide production rates and erosion models, Earth and Planetary Science Letters 104, 424-439, 1991.

T.J. Dunai, Scaling factors for production rates of in situ produced cosmogenic nuclides: a critical reevaluation, Earth and Planetary Science Letters 176, 157-169, 2000.

J.O. Stone, Air pressure and cosmogenic isotope production, Journal of Geophysical Research 105, 23753-23759, 2000.

P.W. Kubik, S. Ivy-Ochs, J. Masarik, M. Frank and C. Schlüchter, ${ }^{10} \mathrm{Be}$ and ${ }^{26} \mathrm{Al}$ production rates deduced from an instantaneous event within the dendro-calibration curve, the landslide of Köfels, Ötz Valley, Austria, Earth and Planetary Science Letters 161, 231-241, 1998.

36 E. Heidbreder, K. Pinkau, C. Reppin and V. Schöenfelder, Measurement of the distribution in energy and angle of high-energy neutrons in the lower atmosphere, Journal of Geophysical Research 76, 2905-2916, 1971.

R. Braucher, D.L. Bourlès, F. Colin, E.T. Brown and B. Boulange, Brazilian laterite dynamics using in situ-produced ${ }^{10} \mathrm{Be}$, Earth and Planetary Science Letters 163, 197-205, 1998.

E.T. Brown, D.L. Bourlès, F. Colin, G.M. Raisbeck, F. Yiou and S. Desgarceau, Evidence for muon induced production of ${ }^{10} \mathrm{Be}$ in near surface rocks from Congo, Geophysical Research Letters 22, 703706, 1995.

M. Schaller, F. von Blanckenburg, N. Hovius and P.W. Kubik, Large-scale erosion rates from in-situ produced cosmogenic nuclides in European river sediments, Earth and Planetary Science Letters 188, 441-458, 2001.

J.L. de Beaulieu and M. Reille, Histoire de la végétation d'après les analyses polliniques. Paléoenvironnements tardiglaciaires et holocènes des lacs de Pélleautier et Siguret (Hautes Alpes, France), Ecologia Mediterranea 9, 19-36, 1983.

41 J. Argant and A. Argant, Mise en évidence de l'occupation ancienne d'un site d'altitude : analyse pollinique du lac du Lauzon, Géologie Alpine, Mémoire Hors Série 31, 61-71, 2000.

42 P. Duchauffour, Abrégé de pédologie, 291 pp., Masson, Paris, 1995.

43 M. Bornand, Altération des matériaux fluvio-glaciaires, genèse et évolution des sols sur terrasses quaternaires dans la moyenne vallée du Rhône, Ph.D., Université du Languedoc, 1978.

A.C. Kurtz, L.A. Derry, O.A. Chadwick and M.-J. Alfano, Refractory element mobility in volcanic soils, Geology 28, 683-686, 2000. 
M. Reille, J.-L. De Beaulieu, H. Svobodova, V. Andrieu-Ponel and C. Goeury, Pollen analytical biostratigraphy of the last five climatic cycles from a long continental sequence from the Velay region (Massif Central, France), Journal of Quaternary Science 15, 665-685, 2000.

E.T. Brown, R.F. Stallard, M.C. Larsen, G.M. Raisbeck and F. Yiou, Denudation rates determined from the acumulation of in-situ produced ${ }^{10} \mathrm{Be}$ in the Luquillo Experimental Forest, Puerto Rico, Earth and Planetary Science Letter 129, 193-202, 1994.

47 D.J. Merrits, K.R. Vincent and E.E. Wohl, Long river profiles, tectonism, and eustasy: A guide to interpreting fluvial terraces, Journal of Geophysical Research 99, 14031-14050, 1994.

S.F. Personius, Late Quaternary stream incision and uplift in the forearc of the Cascadia subduction zone, western Oregon, Journal of Geophysical Research 100, 20193-20210, 1995.

M. Hinderer, Late Quaternary denudation of the Alps, valley and lake fillings and modern river loads, Geodinamica Acta 14, 231-263, 2001.

M. Jorda, T. Rosique and J. Evin, Données nouvelles sur l'âge du dernier maximum glaciaire dans les Alpes méridionales françaises, Comptes Rendus de l'Académie de Sciences, Paris 331, 187-193, 2000.

51 M. Campy, R. Lamy-Rousseau and G. Nicoud, Les modalités de la déglaciation würmienne dans le nord-ouest des Alpes, Geodynamica Acta 4, 211-225, 1990.

E. Chapron, Contrôle climatique et tectonique de la sédimentation lacustre dans l'avant-pays alpin (lac du Bourget) durant le quaternaire récent, PhD., Université de Savoie, 1999.

M.A. Seidl, W.E. Dietrich and J.W. Kirchner, Longitudinal profile development into bedrock: an analysis of Hawaiian channels, Journal of Geology 102, 457-474, 1994.

P.A. van der Beek, A. Pulford and J. Braun, Cenozoic landscape development in the Blue Mountains (SE Australia): lithological and tectonic controls on rifted margin morphology, Journal of Geology 109, 35-56, 2001.

55 J.K. Weissel and M.A. Seidl, Inland propagation of erosional escarpments and river profile evolution across the southeast Australian passive continental margin, in: Rivers over Rock: Fluvial Processes in Bedrock Channels, K.J. Tinkler and E.E. Wohl, eds., Geophysical Monograph 107, pp. 189-206, American Geophysical Union, 1998.

T.W. Gardner, Experimental study of knickpoint and longitudinal profile evolution in cohesive, homogeneous material, Geological Society of America Bulletin 94, 664-672, 1983.

P. Bishop and G. Goldrick, Geomorphological evolution of the East Australian continental margin, in: Geomorphology and Global Tectonics, M.A. Summerfield, ed., pp. 225-254, Wiley, Chichester, 2000.

58 I.J. Winograd, J.M. Landwehr, K.R. Ludwig, T.B. Coplen and A. Roggs, Duration and structure of the past four interglaciations, Quaternary Research 48, 141-154, 1997. 


\begin{tabular}{|c|c|c|c|c|c|c|c|c|c|c|}
\hline Terrace & Sample & $\begin{array}{c}{ }^{10} \mathrm{Be} /{ }^{9} \mathrm{Be} \\
10^{-14}\end{array}$ & $\begin{array}{c}{\left[{ }^{10} \mathrm{Be}\right]} \\
10^{4} \text { at. } g^{-1} \\
\end{array}$ & $\begin{array}{l}\text { Depth } \\
\mathrm{cm}\end{array}$ & $\begin{array}{c}\text { Latitude } \\
\circ\end{array}$ & $\begin{array}{c}\text { Altitude } \\
m\end{array}$ & $\begin{array}{l}\text { Shielding } \\
\text { Factor }\end{array}$ & $\begin{array}{c}\text { Calibration } \\
\text { factor }\end{array}$ & $\begin{array}{c}\mathrm{P}_{1}: \\
\text { at. } g^{-1} \cdot y r^{-1}\end{array}$ & $\begin{array}{c}\text { Apparent exposure age } \\
k y\end{array}$ \\
\hline \multirow{5}{*}{ VILLARD-JULIEN } & Drac 1-0 & 4.858 & $10.9 \pm 1.6$ & 0 & 44,8565 & 775 & 0.9975 & 1.8470 & 10.7 & $10.1 \pm 2.1$ \\
\hline & Drac 1-2 & 6.881 & $8.2 \pm 1.3$ & 35 & 44,8565 & 775 & 0.9975 & 1.8470 & 6.8 & $12.1 \pm 2.6$ \\
\hline & Drac 1-3 & 4.029 & $5.1 \pm 0.9$ & 75 & 44,8565 & 775 & 0.9975 & 1.8470 & 4.0 & $12.6 \pm 2.8$ \\
\hline & Drac 1-5 & 7.595 & $10.8 \pm 1.4$ & 152 & 44,8565 & 775 & 0.9975 & 1.8470 & 1.5 & $72.6 \pm 14.3$ \\
\hline & Drac 1-8 & 1.525 & $1.7 \pm 0.7$ & 292 & 44,8565 & 775 & 0.9975 & 1.8470 & 0.3 & $53.1 \pm 20.3$ \\
\hline \multirow{3}{*}{ CHAUFFAYER } & Drac 5-1 & 13.37 & $6.6 \pm 1.1$ & 90 & 44,7489 & 915 & 0.9942 & 2.0815 & 3.7 & $17.8 \pm 3.9$ \\
\hline & Drac 5-3 & 3.096 & $2.7 \pm 1.3$ & 230 & 44,7489 & 915 & 0.9942 & 2.0815 & 0.7 & $40.7 \pm 17.6$ \\
\hline & Drac 5-5 & 13.66 & $9.0 \pm 1.0$ & 75 & 44,7489 & 915 & 0.9942 & 2.0815 & 4.5 & $20.0 \pm 3.7$ \\
\hline \multirow{3}{*}{ LESTIQUIÈRE } & Drac 6-1 & 5.643 & $3.7 \pm 0.5$ & 25 & 44,6903 & 950 & 0.9980 & 2.1431 & 8.9 & $4.2 \pm 0.8$ \\
\hline & Drac 6-3 & 1.248 & $2.5 \pm 1.1$ & 72 & 44,6903 & 950 & 0.9980 & 2.1431 & 4.8 & $5.1 \pm 1.9$ \\
\hline & Drac 6-4 & 2.446 & $1.5 \pm 1.1$ & 100 & 44,6903 & 950 & 0.9980 & 2.1431 & 3.4 & $4.5 \pm 3.0$ \\
\hline \multirow{3}{*}{ LES ARMANDS } & Drac 7-1 & 9.053 & $5.2 \pm 0.6$ & 30 & 44,9133 & 475 & 0.9777 & 1.4182 & 5.4 & $9.6 \pm 1.8$ \\
\hline & Drac 7-2 & 1.673 & $3.2 \pm 1.2$ & 55 & 44,9133 & 475 & 0.9777 & 1.4182 & 3.9 & $8.1 \pm 2.9$ \\
\hline & Drac 7-4 & 1.394 & $1.2 \pm 0.5$ & 230 & 44,9133 & 475 & 0.9777 & 1.4182 & 0.5 & $27.0 \pm 9.6$ \\
\hline \multirow{2}{*}{ LE TUVE } & Drac 8-1 & 4.326 & $9.5 \pm 1.4$ & 40 & 44,6680 & 1025 & 0.9945 & 2.2837 & 7.8 & $12.1 \pm 2.5$ \\
\hline & Drac 8-3 & 11.82 & $7.1 \pm 0.8$ & 70 & 44,6680 & 1025 & 0.9945 & 2.2837 & 5.3 & $13.6 \pm 2.5$ \\
\hline BLANK1 & & 0.4692 & & & & & & & & \\
\hline \multirow{3}{*}{ EYGAUX } & Buech 1-1 & 448.2 & $227.3 \pm 12.5$ & 0 & 44,5213 & 965 & $\sim 1$ & 2.1655 & 12.6 & $189.0 \pm 30.2$ \\
\hline & Buech 1-2 & 440.1 & $212.3 \pm 16.3$ & 0 & 44,5213 & 965 & $\sim 1$ & 2.1655 & 12.6 & $176.0 \pm 29.7$ \\
\hline & Buech 1-3 & 259.2 & $173.7 \pm 9.5$ & 0 & 44,5213 & 965 & $\sim 1$ & 2.1655 & 12.6 & $142.8 \pm 22.8$ \\
\hline \multirow{3}{*}{ ASPRES SUR BUECH } & Buech 2-1 & 124.2 & $63.2 \pm 3.8$ & 0 & 44,5065 & 815 & 0.9696 & 1.9031 & 10.7 & $59.9 \pm 9.7$ \\
\hline & Buech 2-2 & 37.63 & $23.4 \pm 2.6$ & 0 & 44,5065 & 815 & 0.9696 & 1.9031 & 10.7 & $22.0 \pm 4.1$ \\
\hline & Buech 2-3 & 20.37 & $10.8 \pm 1.3$ & 0 & 44,5065 & 815 & 0.9696 & 1.9031 & 10.7 & $10.1 \pm 1.9$ \\
\hline \multirow{3}{*}{ LA BATIE-MONTSALEON } & Buech 3-1 & 3.447 & $3.6 \pm 0.8$ & 55 & 44,4570 & 720 & 0.9625 & 1.7509 & 4.8 & $7.6 \pm 2.0$ \\
\hline & Buech 3-4 & 3.065 & $3.8 \pm 1.0$ & 80 & 44,4570 & 720 & 0.9625 & 1.7509 & 3.4 & $11.1 \pm 2.7$ \\
\hline & Buech 3-5 & 1.682 & $1.0 \pm 0.5$ & 224 & 44,4570 & 720 & 0.9625 & 1.7509 & 0.6 & $16.4 \pm 5.2$ \\
\hline BLANK2 & & 0.2749 & & & & & & & & \\
\hline BLANK3 & & 0.9618 & & & & & & & & \\
\hline
\end{tabular}

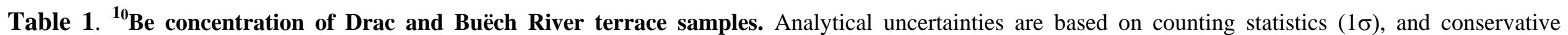
assumptions of $5 \%$ variability in accelerator response based on a $15 \mathrm{y}$ counting record. Replicate counts errors are the main source of total error fluctuations as some samples have ground-level concentrations. ${ }^{10} \mathrm{Be}^{9} \mathrm{Be}_{\mathrm{NIST}}=2,68.10^{-11}$. Sea-level-high-latitude production rate $\mathrm{P}_{0}: 5.75$ at. ${ }^{-1}$.an ${ }^{-1}[33]$. $\mathrm{P}_{1}: \mathrm{P}_{0}$ corrected from shielding factor, latitude, altitude, neutron and muon captures with depth. Shielding factor from [34]. Latitude and altitude factors calibrated from [31]. Soil density : 2.0 g. $\mathrm{cm}^{-2}$. 


\begin{tabular}{|c|c|c|c|}
\hline \multicolumn{4}{|c|}{ ICP-AES } \\
\hline & soil & \begin{tabular}{|l|} 
alluvium \\
\end{tabular} & \multirow{2}{*}{$\begin{array}{l}\text { Enrichment factor } \\
\text { Corrected for LOI }\end{array}$} \\
\hline & \multicolumn{2}{|c|}{$\mathrm{Wt} \%$} & \\
\hline $\mathrm{SiO}_{2}$ & 79,45 & 30,72 & 1.99 \\
\hline $\mathrm{Al}_{2} \mathrm{O}_{3}$ & 7,84 & 4,78 & 1.26 \\
\hline $\mathrm{Fe}_{2} \mathrm{O}_{3}$ & 3,08 & 1,94 & 1.22 \\
\hline $\mathrm{MnO}$ & 0,14 & 0,09 & 1.20 \\
\hline $\mathrm{MgO}$ & 0,5 & 0,62 & 0.62 \\
\hline $\mathrm{CaO}$ & 0,32 & 32,79 & 0,01 \\
\hline $\mathrm{Na}_{2} \mathrm{O}$ & 0,8 & 0,47 & 1,31 \\
\hline $\mathrm{K}_{2} \mathrm{O}$ & 1,45 & 0,91 & 1,23 \\
\hline $\mathrm{TiO}_{2}$ & 0,35 & 0,16 & 1.69 \\
\hline $\mathrm{P}_{2} \mathrm{O}_{5}$ & 0,06 & $<$ D.S & \\
\hline Loss on Ignition & 5,82 & 27,31 & \\
\hline with $\mathrm{CO}_{2}$ & 1,232 & 22,176 & \\
\hline and $\mathrm{H}_{2} \mathrm{O}$ & 4,588 & 5,134 & \\
\hline Total & 99,81 & 99,83 & \\
\hline \multicolumn{4}{|c|}{ ICP-MS } \\
\hline \multirow[t]{2}{*}{ Loss on Ignition } & 6,09 & 27,28 & \\
\hline & \multicolumn{2}{|c|}{ ppm } & \\
\hline${ }^{232} \mathrm{Th}$ (ppm) & 4.37 & 2.07 & 2.11 \\
\hline${ }^{181} \mathrm{Ta}(\mathrm{ppm})$ & 0,39 & 0,19 & 2,01 \\
\hline
\end{tabular}

Table 2. Major and trace elements contents of alluvium and soil at the T3 terrace sampling site, and enrichment factors. D.S: detection threshold. $\mathrm{CO}_{2}$ fraction in loss on ignition measured on fresh powder by Lambert calcimetry.

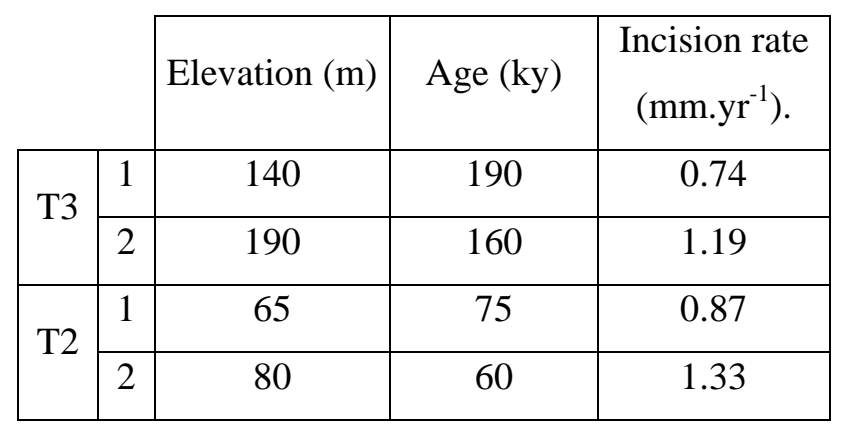

Table 3. Buëch River incision rates infered from CRE dating. 


\section{Figure Captions}

Fig. 1. Location of main rivers, dated terraces and major tectonic thrusts within the study area. The Miocene subalpine ranges include the Digne thrust sheet and the Vercors and Chartreuse massifs. ECM: External Crystalline Massif.

Fig. 2. Late Glacial Maximal extent of alpine glaciers and ice-dammed lakes within the study area. Modified from [27].

Fig. 3. Longitudinal profile of the Buëch River with terrace surfaces projected onto the valley axis, showing location of the CRE sampling sites and the relationships between terraces and glacial advances.

Fig. 4. Terraces types encountered along the Drac River; valley cross-sections at two of the CRE sample sites (modified from [27]). (A.) Fill terrace generated by an ice-dam located downstream (Drac 1) and strath terrace cut into bedrock and fill terrace deposits during subsequent river entrenchment (Drac 7). (B.) Fill terrace formed by infilling of the Séveraisse Glacier frontal trough. 1: bedrock. 2: lacustine sediments. 3 : glacial till (outer unit). 4: glacial till (inner unit). 5: river deposits.

Fig. 5. (A.) Drac River longitudinal profile with terrace and moraine surfaces projected onto the valley axis. The CRE sampling sites are indicated, as well as the material incised during river entrenchment. (B.) Detail of lithological units incised by the Drac River after the inception of glacier retreat, projected onto the valley axis. Glacier profiles show the maximal extent of each glacier during the last glaciation.

Fig. 6. ${ }^{10} \mathrm{Be}$ concentration profiles of the Drac River terraces. Diamonds and error bars: measured ${ }^{10} \mathrm{Be}$ contents (sample number indicated). Solid lines: upper and lower accepted concentration profiles. Models are accepted if they fit all the data points within error. Best-fit (based on RMS residuals) and accepted age ranges are indicated in the lower right (unit: ky). See text for discussion.

Fig. 7. Exposure ages and inheritance for the Drac terraces. Upper diagram shows the sample site location along the Drac river valley and incision rates inferred from ${ }^{10} \mathrm{Be}$ ages (arrows with italic numbers). K: propagating knickpoint. Lower diagram shows terrace ages (confidence and best-fit intervals) and inherited ${ }^{10} \mathrm{Be}$ assessed using the concentration profile modelling (Fig. 6). The assessed ${ }^{10} \mathrm{Be}$ inherited concentrations are expressed as equivalent inherited ${ }^{10} \mathrm{Be}$ ages, that is, times required to reach these concentrations in the case of in situ accumulation at the terrace surfaces.

Fig. 8. Modelling of the cumulative effects of weathering and wind erosion on ${ }^{10} \mathrm{Be}$ age scattering of surficial clasts at Buëch T3 terrace. (A.) exhumation path of quarztite pebbles originally buried at $0.5 \mathrm{~m}$ and $1.0 \mathrm{~m}$ in case of linear or decreasing dissolution of carbonates and subsequent matrix erosion at constant rates of 0.2 $\mathrm{cm} / \mathrm{ky}$ (path 2) and $0.4 \mathrm{~cm} / \mathrm{ky}$ (path 3). (B.) Resulting Apparent Surficial Ages (ASA); ASA correspond to 
the time required to reach the measured ${ }^{10} \mathrm{Be}$ concentration in a pebble remaining at the surface during the entire accumulation history. Solid lines: ASA vs. original depth, dashed lines: ASA vs. final depth. Paths: linear or decreasing carbonate dissolution during the last interglacial period (130-75 ky), with no erosion latter (1,1'); 2, 3: with wind erosion at $0.2 \mathrm{~cm} / \mathrm{ky}\left(2,2^{\prime}\right)$ and $0.4 \mathrm{~cm} / \mathrm{ky}\left(3,3^{\prime}\right)$ during the last glaciation . Sample Buëch 1-3 was eroded at a rate exceeding (2).

Fig. 9. Evaluation of the long-term incision rate of the Buëch River. White boxes indicate individual measurements of CRE ages with errors; black boxes stand for the triple error overlap of the Buëch 1 samples and, at the Buëch 3 sampling site, for the best-fitting profile age interval. The stippled regions labelled 'A.L' indicate the thickness of the Alluvial Layer of terrace deposits overlaying the bedrock straths at T2 and T3. Solid lines: maximum (a) and minimum (b) long-term incision rates. Dashed line (c): incision rate in the case of instantaneous incision of alluvial layer; dashed line (d): in the case of equal incision rate within alluvium and underlying bedrock. $\delta^{18} \mathrm{O}$ isotopic curve in lower panel is after [58]. Dark dashed bars indicate isotopic cold stages; lighter shading indicates major European glaciations.

Fig. 10. Post-glacial evolution of the Drac River long profile, inferred from ${ }^{10} \mathrm{Be}$ terrace ages. Inferred subsequent river long profiles are indicated by dashed lines and annotated by age. These profiles, as well as glacier profiles and incised lithological units are projected onto the valley axis.

Fig. 11. Plot of logarithm of river gradient vs. logarithm of downstream distance (D.S. plot) for the Drac River. Inset shows the entire long profile and the location of the studied reaches. Propagating knickpoint (solid star) breaks the profile in two segments. Lithological knickpoints (open stars) occur in reaches where the river flows over crystalline rocks and Mesozoic sediments (bedrock zone). 

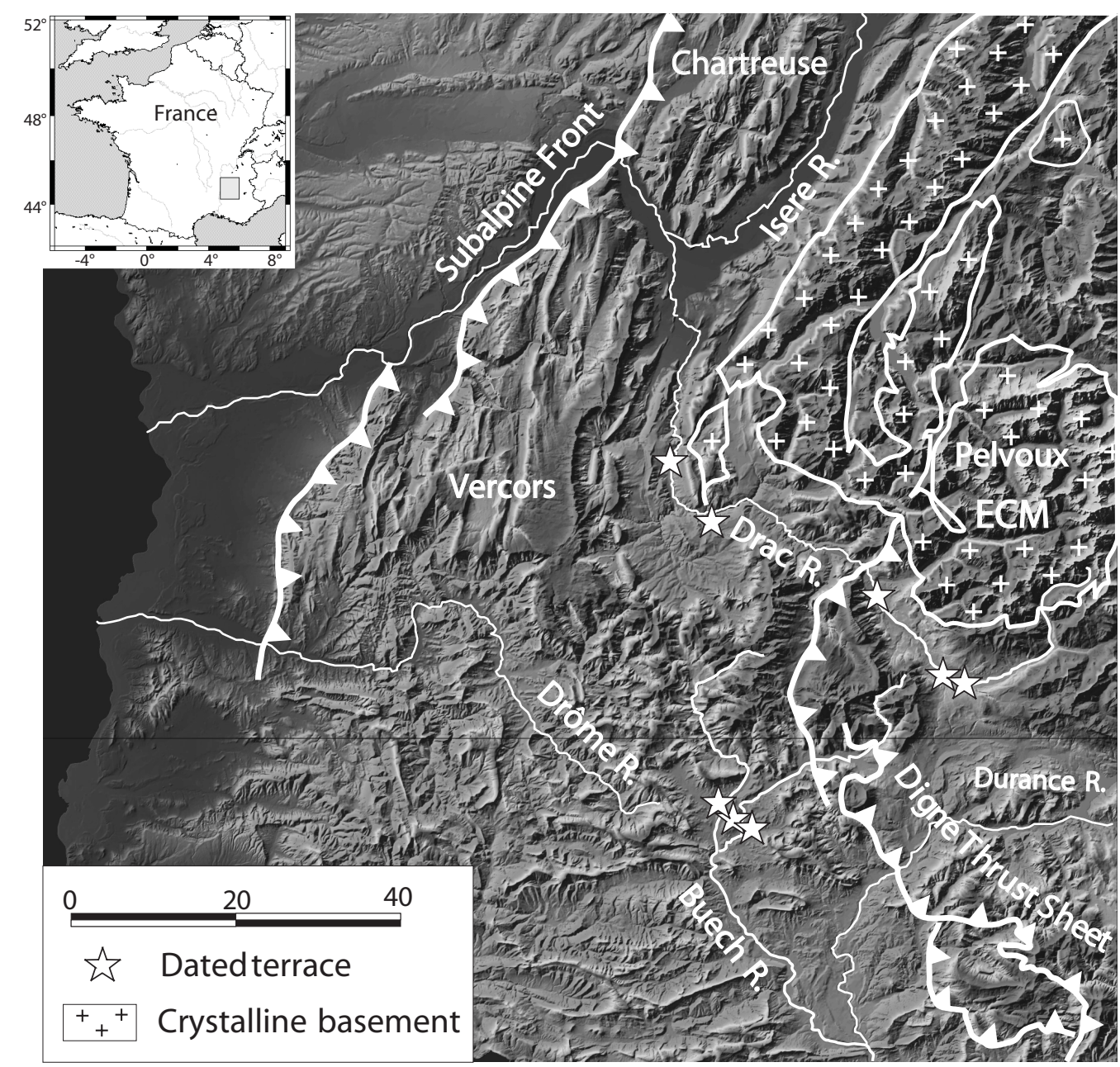

Brocard et al.,

Figure 1 


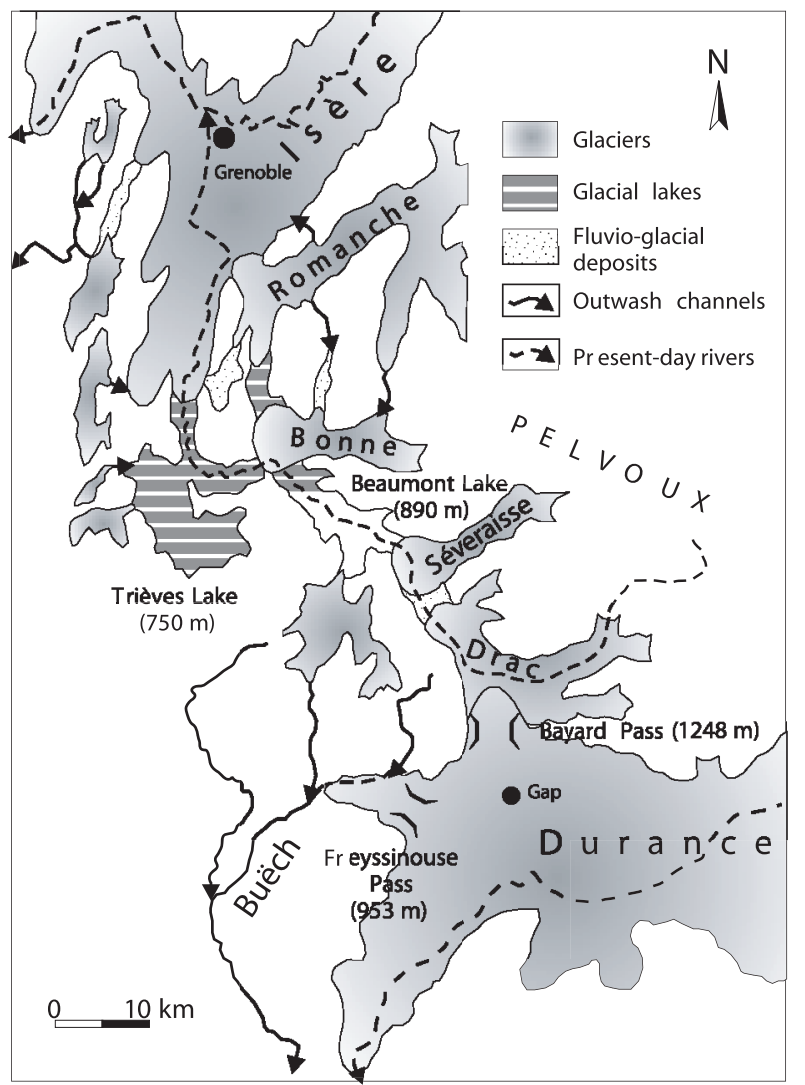

Brocard et al.,

Figure 2 


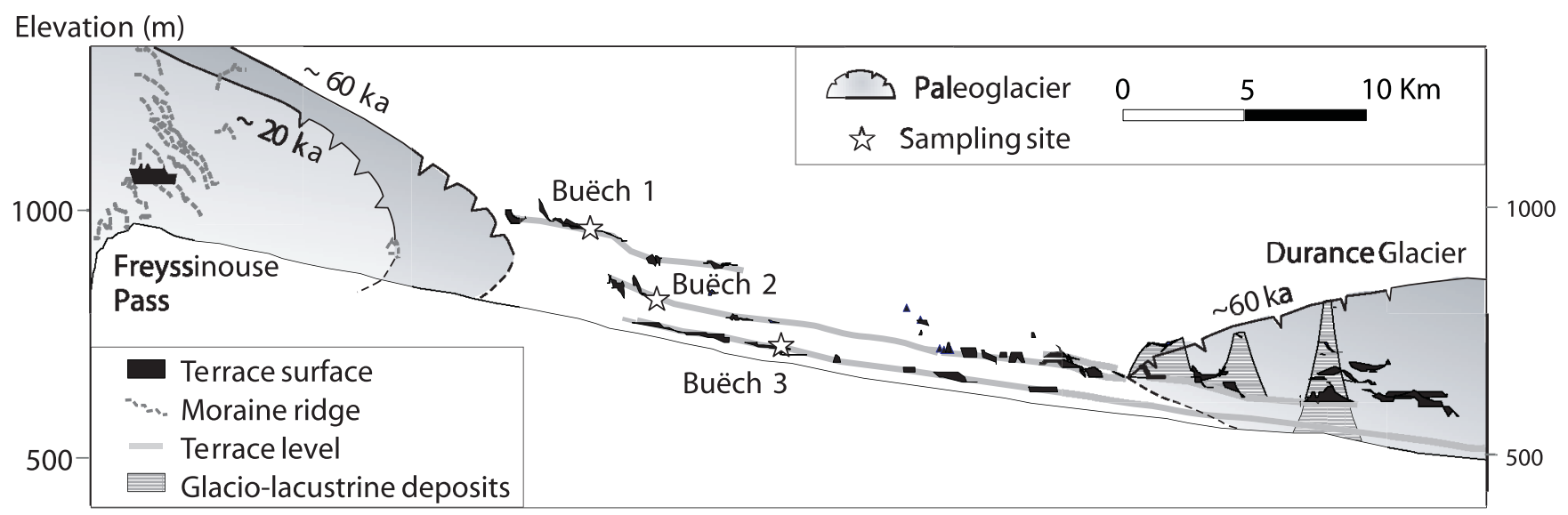

Brocard et al.,

Figure 3 
A.

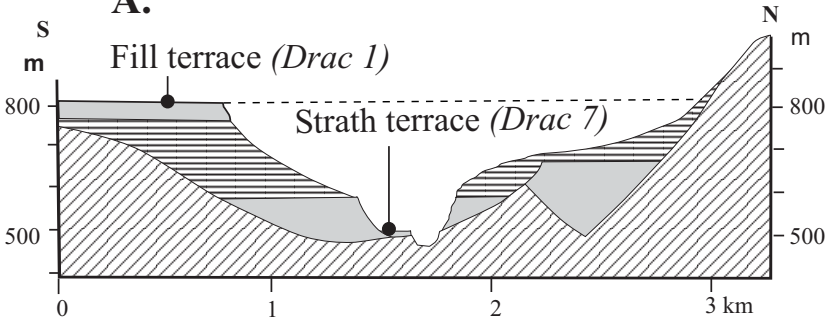

B.

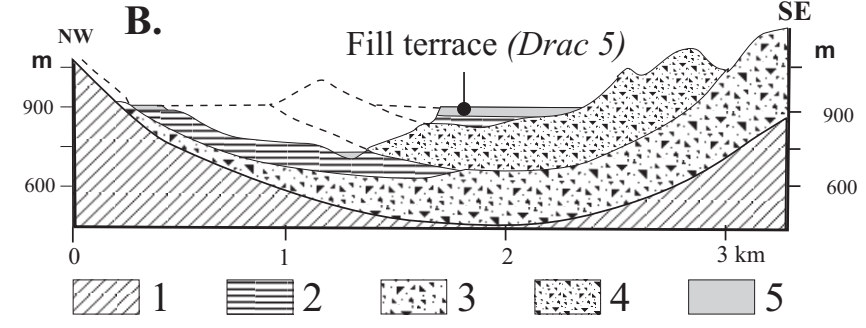


Elevation (m)

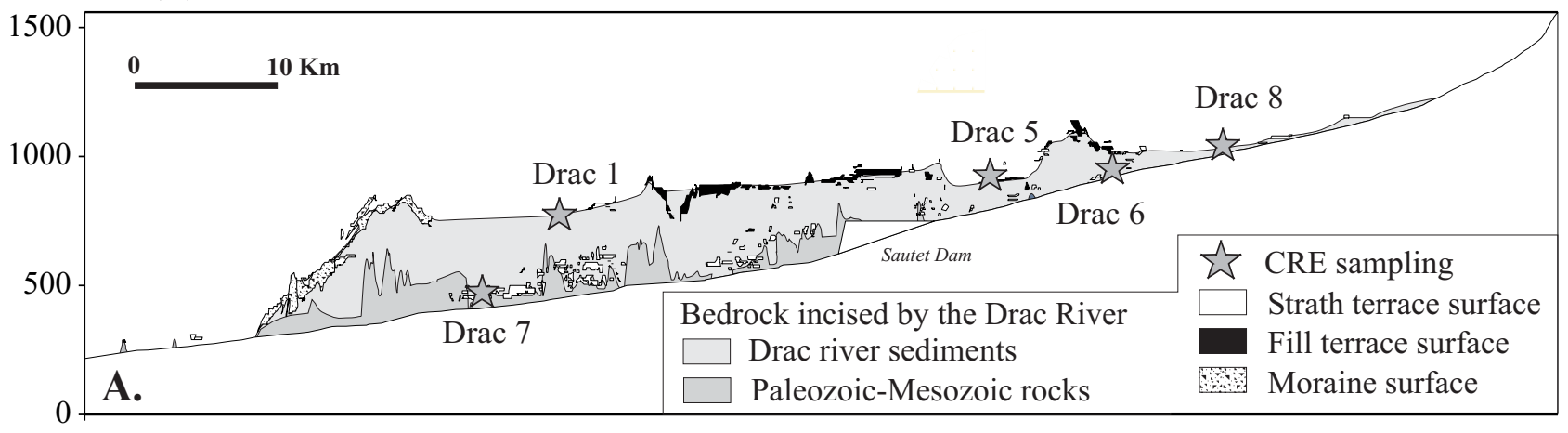

Elevation (m)

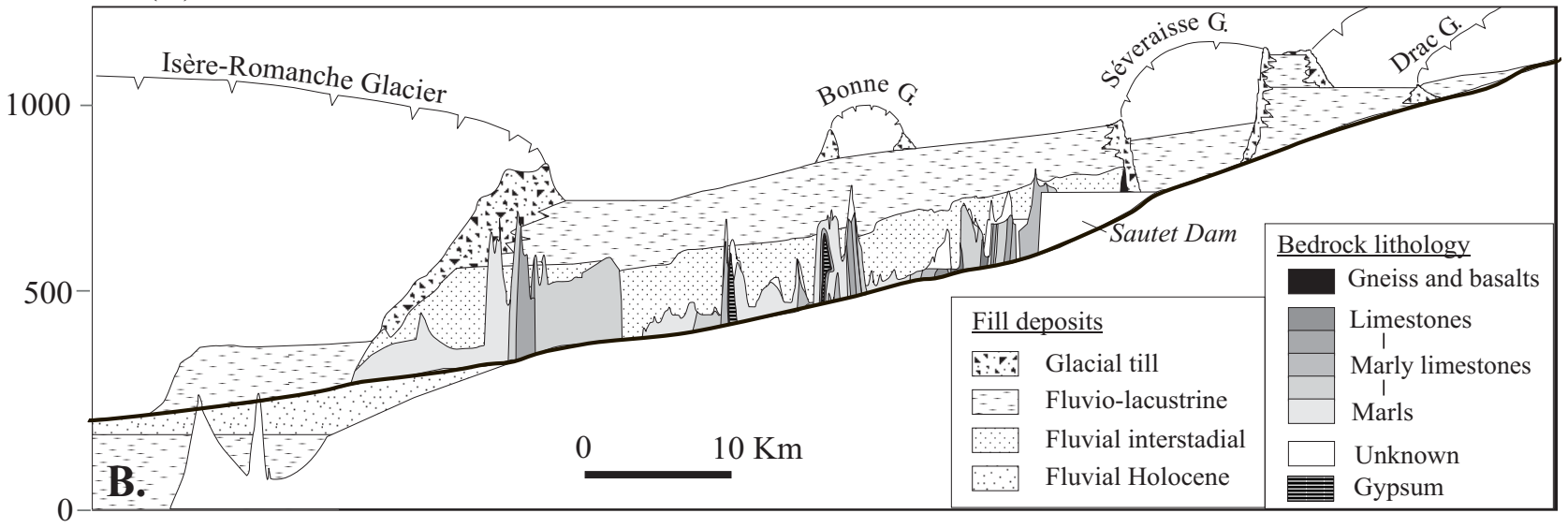

Brocard et al., Figure 5 


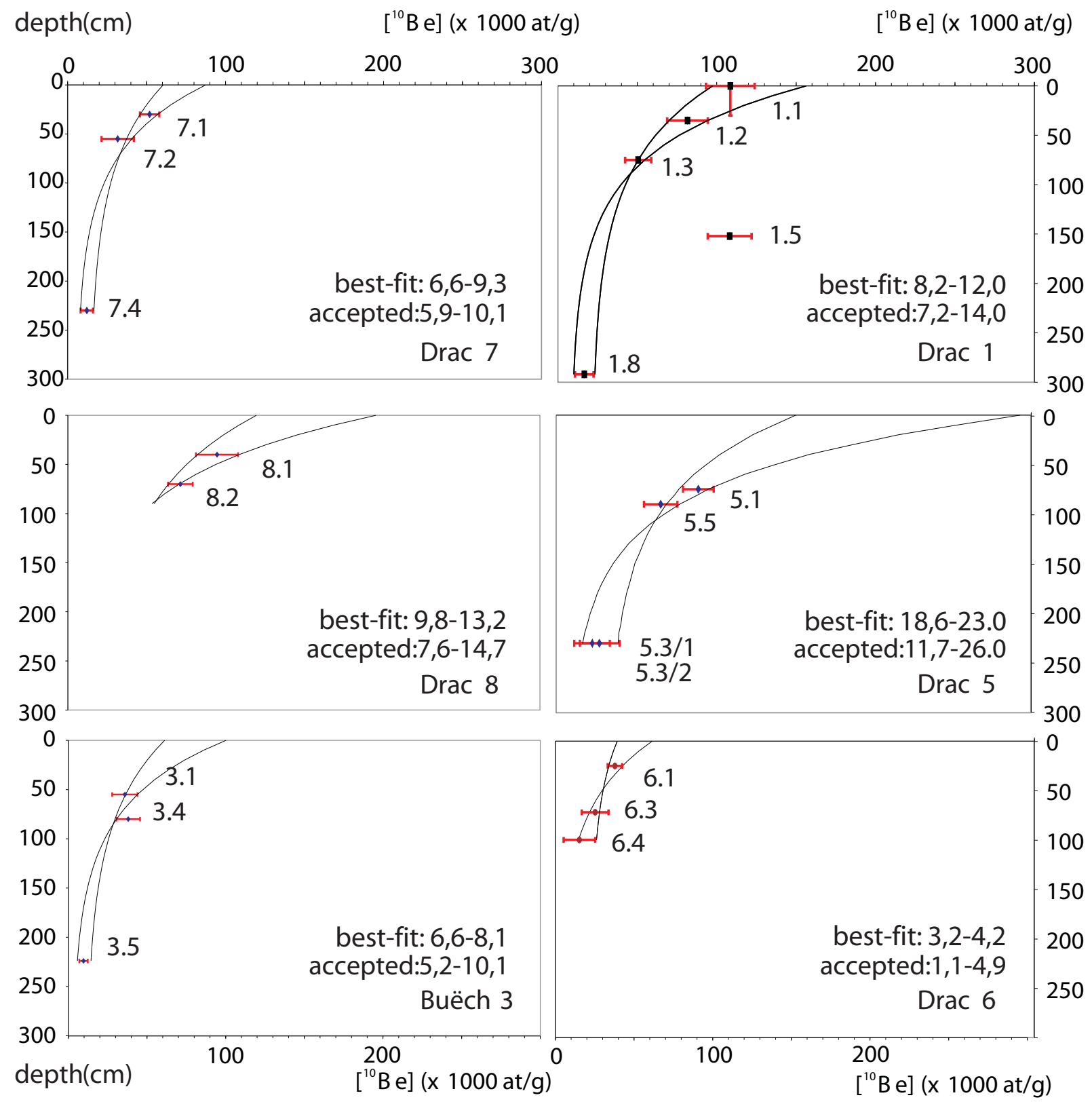

Brocar d e t al., Figure 6 


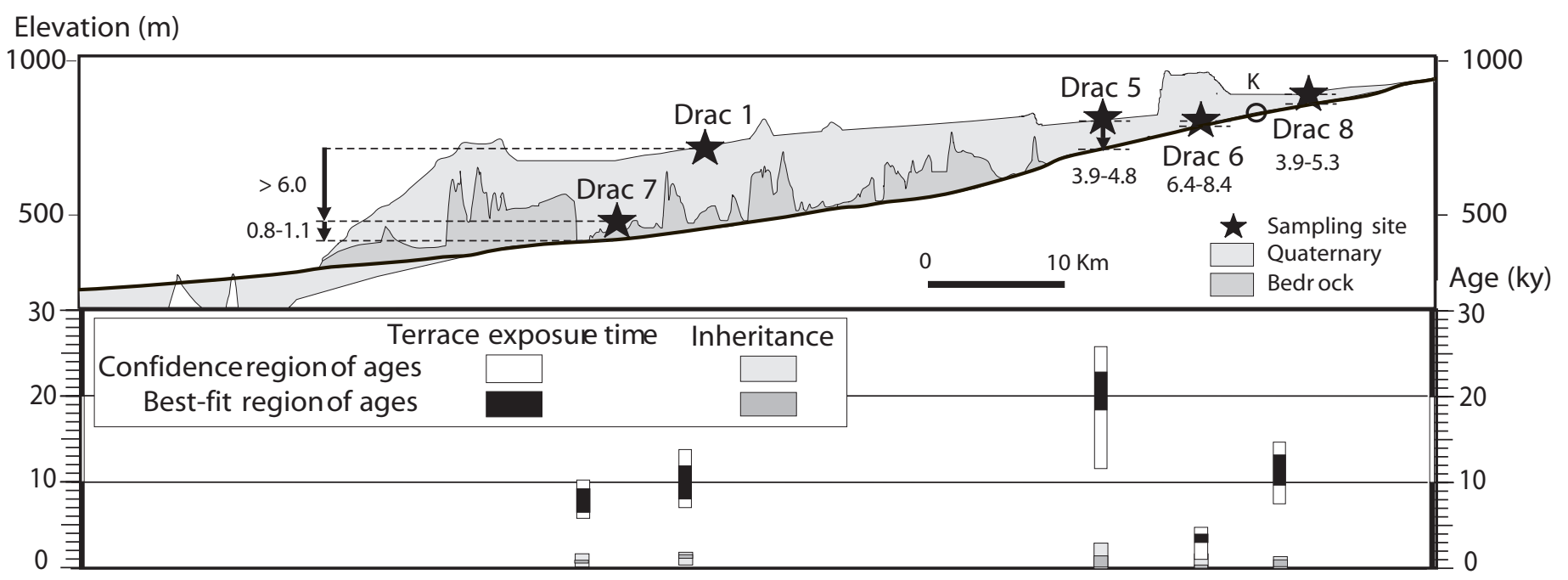




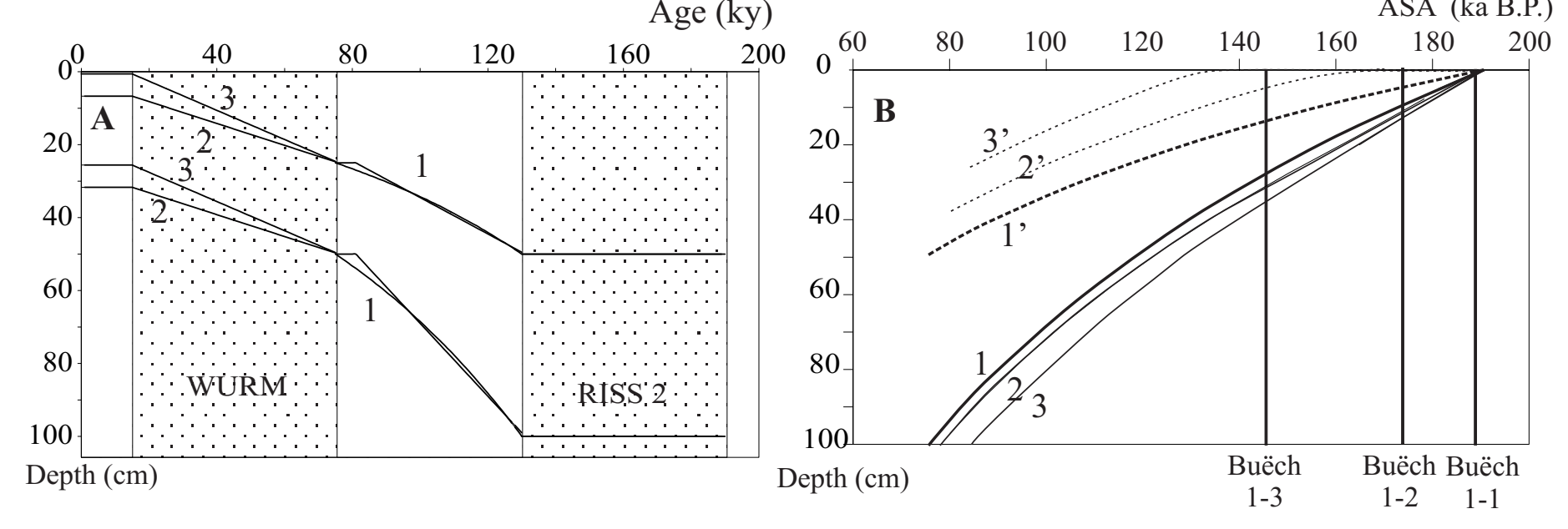



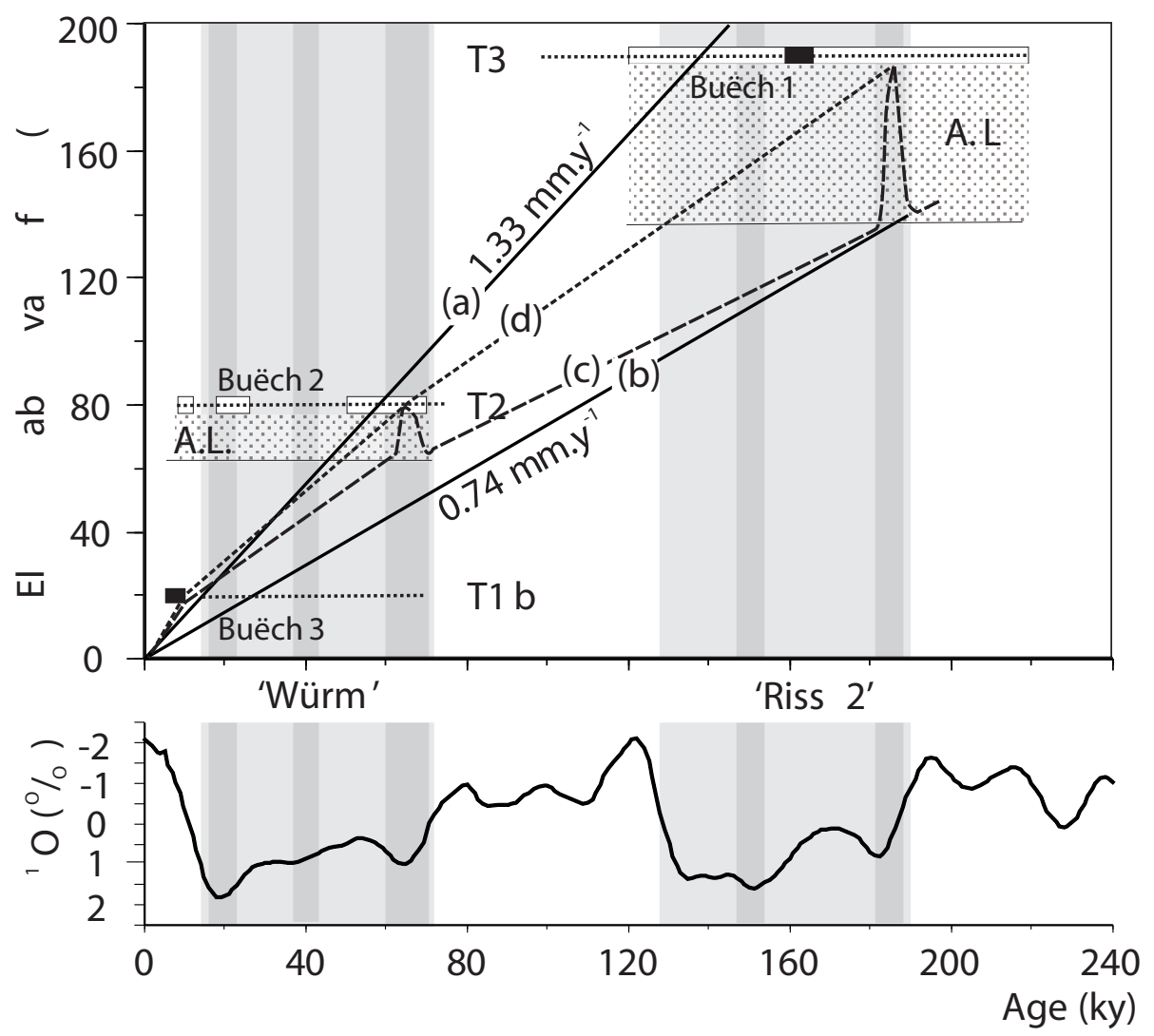

Brocard et al.,

Figure 9 


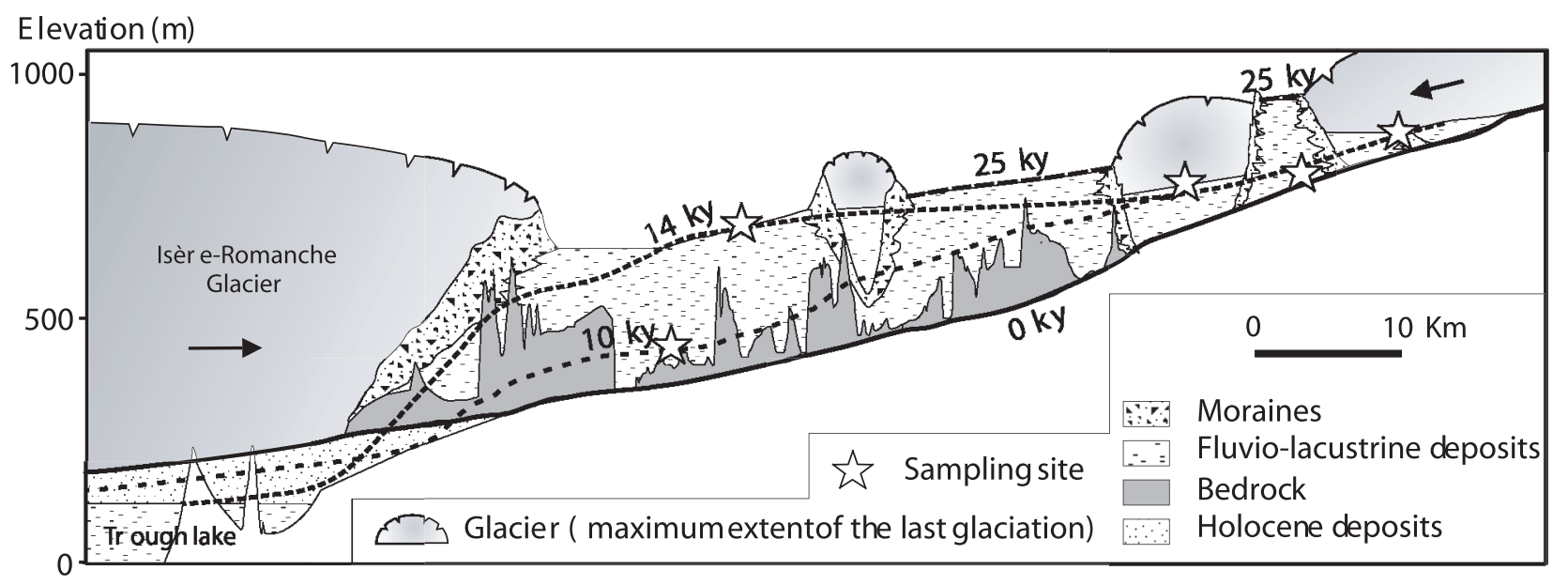

Brocard et al.,

Figure 10 


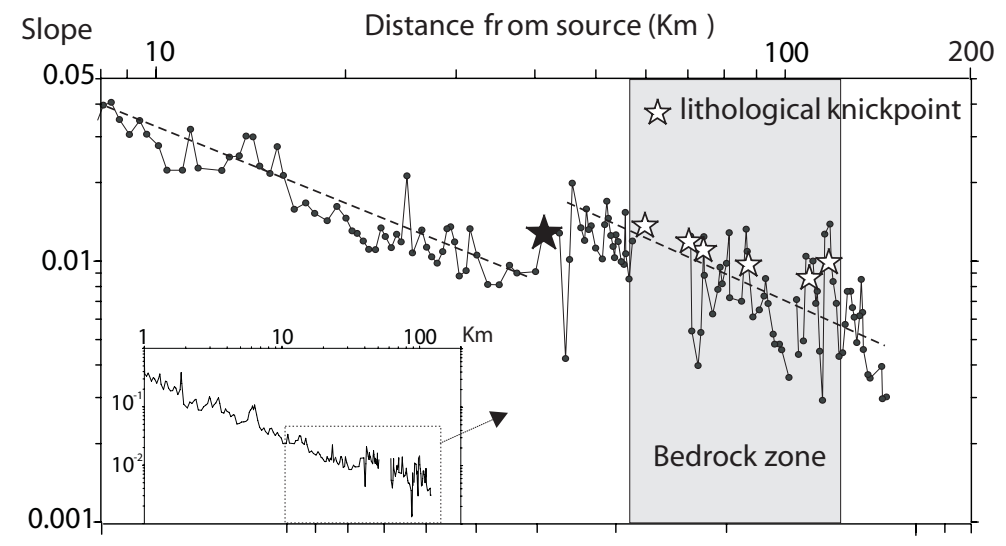

Brocard et al.,

Figure 11 